\title{
4.1 MEASURING CORPORATE SOCIAL RESPONSIBILITY PRACTICES DEDICATED TO EMPLOYEES IN CENTRAL AND SOUTHEASTERN EUROPE - AN EMPIRICAL APPROACH
}

\begin{abstract}
Summary: Nowadays, the human resources are considered the main factor for consolidating corporate competitiveness in the international business arena, especially taking into account the most recent transformations that deeply affected the economic and social environment in Central and Southeastern Europe. Following this argument, the objective of our research paper consists in emphasizing the role of corporate social responsibility (CSR) practices in the area of human resource management (HRM) for strengthening the competitiveness of companies in Central and Southeastern Europe. In this sense, our research focuses on top companies ranked by turnover in Bulgaria, Czech Republic, Hungary, Poland, Romania, Slovakia and Slovenia, for which we determined by computation four innovative composite indices of CSR-HR in order to compare the corporate engagement in a set of employeerelated issues. The main issues, or pillars, that we took into account envisage the following: improvement of labour conditions and job satisfaction, work-private life balance, equal opportunities and promotion of diversity, personnel training and development, participation of employees in the decision-making process, fair payment and financial support for employees. In accordance with other studies in the field, the main findings reflect that the economic performance of the companies encourages the overall CSR measures targeting the employees in the companies from Central and Southeastern Europe countries. Detailed findings on the corresponding components of the CSR-HR index are also presented and justified. The paper ends with a suite of strategic recommendations for increasing corporate competitiveness in Central and Southeastern Europe through the CSR-HR continuum, while the findings could be extrapolated to more companies and countries.
\end{abstract}

Keywords: Corporate social responsibility (CSR), Human resource management (HRM), Competitiveness, CSR-HR composite index, Employee-dedicated CSR measures

\section{INTRODUCTION}

After the most recent economic crisis, the societal pressure put upon companies to increase their corporate social responsibility (CSR) is stronger than ever considering its positive impact for all the stakeholders. In order to better reflect and align to the changes in nowadays business environment, the European Commission has recently proposed a new definition of CSR - "the responsibility of enterprises for their impacts on society"(EC 2011, p. 6), broadly determining the economic, environmental and social influences of the business activities. Furthermore, the European Commission considers that "through CSR, enterprises can significantly contribute to the European Union's treaty objectives of sustainable development and a highly competitive social market economy" (EC, 2011, p. 3).

The global crisis has also changed the corporate priorities in addressing CSR issues, moving the spotlight from environmental issues to social issues. In the extensive category of the social issues that the companies may address, one key-element refers to consolidating the sustainability of their human resources management (HRM) - a term that could be defined as 'the sum of corporate actions and measures for recruiting, selecting, managing, training, evaluating and motivating the personnel'. This is why the employee-related CSR policies are gaining more ground in the specialized literature and the empirical evidence.

Analysing the specialized literature within the field, a bidirectional relationship could be established between corporate social responsibility (CSR) and human resource management 
(HRM): on one hand, the involvement of the employees is a critical factor for the success of the CSR campaigns and, on the other hand, the companies should specifically implement coherent and dedicated CSR policies for their employees (a prerequisite for assuring the CSR engagement of the employees).

The above relationship is approached in a different way at international level: the efforts in the most developed countries are mainly directed to attracting the employees in supporting the CSR agenda of the companies in order to reaffirm the corporate legitimacy (e.g. Strandberg 2009 , for a description of the situation in Canada), meanwhile in the rest of the countries the companies are striving for satisfying the needs of their employees by including CSR in their HR policies. The present research - conducted at the level of the Central and Southeastern Europe (Bulgaria, Czech Republic, Hungary, Poland, Romania, Slovakia and Slovenia) emphasizes the role of CSR in developing a highly articulated HR policy, taking into account the decisive role that the employees play in strengthening the corporate competitiveness and the need of the business organizations to put a greater focus on their employee-dedicated CSR measures.

\section{LITERATURE REVIEW ON CSR AND HRM}

The potential of CSR to increase corporate competitiveness and to bring benefits in terms of risk management, cost savings, access to capital, customer relationships, human resource management, and innovation capacity (EC 2011, p. 3) is now generally acknowledged (see, for example, Iamandi 2011, pp. 180-187, Iamandi 2010, pp. 290-294, Popa \& Filip 1999, p. 257). More than that, some of the most significant changes in the management science emphasized in the specialized literature (Nicolescu 2001) could be easily associated with, or derived from, the concept of CSR and applied specifically to HRM field: innovation, flexibility, motivation and participative management.

The key advantages that CSR brings to the responsible companies in terms of HRM refer to attracting and keeping high quality and well-motivated employees that could internalize and transmit further on the corporate values in their interactions with other stakeholders. The series of CSR measures for employees is broad and it depends on the corporate sectors and activities performed by employees. In this line of thinking, CSR at the workplace covers everything ranging from available training and further education, preventive health measures and risk management to worker participation, equal opportunities, compatibility of career and family, measures against workplace harassment and specific CSR actions for employees such as corporate volunteering (Inno Train CSR). The employee-dedicated CSR measures reflect at least the following six areas:

- Improvement of labour conditions, including health, safety and security at work, and enhancement of job satisfaction;

- Work-life balance;

- Equal opportunities and promotion of diversity at the workplace;

- Training and personal development, including career planning;

- Informing and participation of employees in the decision-making process;

- Responsible and fair remuneration and/or financial support for the employees (e.g. pension systems, interest-free loans etc.) (Austrian Institute for SME Research 2007,p.4).

The recognition of corporate involvement in specific CSR areas is often complemented with a quantitative approach required by third-party auditors. One of the most well-known methods for measuring and evaluating the corporate involvement is represented by the Global Reporting Initiative (GRI 2011) Sustainability Guidelines, presenting a set of complete indicators that companies could use in order to determine their level of compliance in the following CSR fields: Economic, Environmental and Social ('Labour Practices and Decent 
Work', 'Human Rights', 'Society' and 'Product Responsibility'). The employee-dedicated CSR measures fall under the categories of indicators 'Labour Practices and Decent Work' (Employment, Labour-Management Relations, Occupational Health and Safety, Training and Education, Diversity and Equal Opportunity, Equal Remuneration for Women and Men) and 'Human Rights' (Investment and Procurement Practices, Non-discrimination, Freedom of Association and Collective Bargaining, Child Labour, Prevention of Forced and Compulsory Labour, Security Practices, Indigenous Rights, Assessment, Remediation)(GRI 2011, p. 30,33).

\section{EMPIRICAL ANALYSIS OF THE CSR-HR CONTINUUM IN CENTRAL AND SOUTHEASTERN EUROPE}

Our empirical analysis examined the CSR-HR continuum by focusing on an original composite index, the CSR-HR-DAW Index, and on its six pillars, reflecting the described basic employee-dedicated CSR measures. Therefore, the CSR-HR binomial was investigated both from an overall perspective (taking into account revenues from sales, country of origin, operating country and industry field) and a particular perspective (analysing the individual components of the index).

\subsection{DATA AND RESEARCH METHODOLOGY}

In order to study the CSR-HR continuum, our research focused on top companies from the following seven Central and Southeastern Europe countries: Bulgaria, Czech Republic, Hungary, Poland, Romania, Slovakia and Slovenia. More precisely, we chose strictly the first five companies, from each country, ranked by revenues from sales 2009 within the Deloitte CE Top 500 Companies Ranking Report 2010 (Deloitte 2010), so as to reflect the economic performance component of our research. For revealing the CSR-HR continuum, we took into account six fundamental employee-oriented measures, entitled either 'components' or 'pillars': Improvement of labour conditions \& job satisfaction, Work-private life balance, Equal opportunities \& promotion of diversity, Personnel training \& development, Participation of employees in the decision-making process, and Fair payment \& financial support for employees. The data regarding these measures was collected from several available public documents and on-line sources, such as: the CSR reports, the Sustainability reports, the CSR/Sustainability sections in the corporate annual reports, the corporate codes of ethical conduct and other on-line sources on the companies' websites.

Therefore, our original approach consisted in developing four CSR-HR composite indices by grading the six before mentioned pillars, at the level of each of the 35 companies, while considering the following assessment criteria:

- 0 , for no mentioning of the pillar;

- 1 , for an average application of the pillar, compared within the overall sample;

- 2 , for an excellent application of the pillar, compared within the overall sample.

Further, the method of computation consisted in averaging the six values, for each company, in order that the maximum value of each CSR-HR composite index be equal to 1 . Taking into account that we are interested in the development stage reached by the companies from the point of view of CSR in HR, in our research we only took into account the most recent publicly and freely available CSR sources from the previously mentioned ones. Furthermore, taking into account that CSR could also strategically reveal the image of the company and, correspondingly, considering that there are many companies that report every two years on their sustainability strategies, we reflected the "Data Availability" criterion, by weighting the CSR-HR composite indices as follows:

- 1.0, when the data was available for the 2010-2011 period; 
- 0.9 , when the data was available for the 2009-2010 period;

- 0.8, when the data was available for the 2008-2009 period.

Thus, we developed the following CSR-HR-DAW Composite Indices (Corporate Social Responsibility - Human Resources - Data Availability Weighted Indices):

- The Global CSR-HR-DAW Index, an overall index that encompasses the performance of all the six pillars;

- The Broad Development CSR-HR-DAW Index, built as an aggregation of the Personnel training \& development and the Work-private life balance components;

- The Inclusive Concern CSR-HR-DAW Index, derived from combination of the Improvement of labour conditions \& job satisfaction and the Participation of employees in the decision-making process components;

- The Right Reward CSR-HR-DAW Index, including the Fair payment \& financial support for employees and the Equal opportunities \& promotion of diversity components.

While the first index aims at measuring the CSR-HR continuum holistically, the last three indices target to quantify the CSR in HR by considering a more analytic approach and focusing on three broad constituents (the assistance that the employees receive for their comprehensive development, the consideration of the employees in their job life and the allocation of the remuneration benefits received by employees).

In addition, we weighted each of the 6 pillars by considering the data availability criterion and we developed individual corporate scores, as follows:

- Improvement of labour conditions \& job satisfaction - DAW;

- Work-private life balance-DAW;

- Equal opportunities \& promotion of diversity-DAW;

- Personnel training \& development-DAW;

- Participation of employees in the decision-making process - DAW;

- Fair payment \& financial support for employees - DAW.

Taking into account the previously described CSR-HR continuum measures, we developed our research investigation on two levels:

1) We explored the performance of the CSR-HR-DAW Indices within a twofold analysis:

- in relation with an economic variable (i.e. revenues from sales);

- by comparing their average values at industry, country of origin and operating country levels.

2) We examined the performance of each of the six pillars relative to the same economic variable - revenues from sales.

\subsection{MAIN FINDINGS}

Firstly, as previously specified, we analysed the CSR-HR continuum by focusing on the performance of the four composite indices and, secondly, by emphasizing some evidences regarding each of the six CSR-HR components.

\subsubsection{The performance of the CSR-HR-DAW Indices}

As Figure 1 illustrates, it seems that the index reflecting the global CSR-HR continuum at the level of the analysed companies exhibits a slight positive trend with respect to the rank of the companies within the Deloitte CE Top 500 Companies, developed by considering revenues from sales. This finding reflects that the economic performance of the companies, 
mirrored by the revenues from sales, encourages the overall CSR measures targeting the employees of the 35 selected companies from Central and Southeastern Europe countries.

Figure 1: The performance of the Global CSR-HR-DAW Index

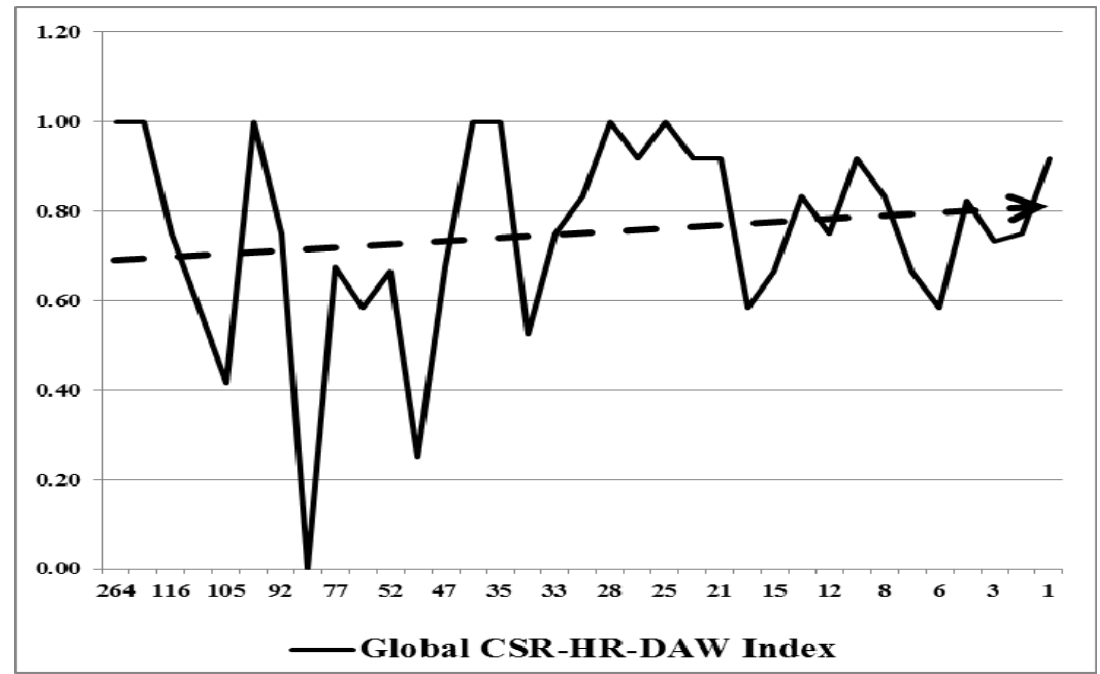

Source: Authors' representation using Deloitte 2010 report data and various CSR reporting sources.

While taking into account the three broad constituent indices, the analysis conducted considering the rank of the companies according to their revenues from sales (see Figure 2) shows that The Broad Development CSR-HR-DAW Index and the Right Reward CSR-HRDAW Index exhibit a moderate and a strong positive trend, respectively, while the Inclusive Concern CSR-HR-DAW Index displays a moderate negative trend. Consequently, there seems that the economic performance of the companies boosts both the broad development and the right reward measures for employees, at the expense of the inclusive concern measures for employees. The explanation resides in the willingness of the top analysed companies in Central and Southeastern Europe countries for dedicating more financial resources in support of their employees or for promoting equal opportunities at work with a direct pragmatic corporate interest than to encourage the employees to involve themselves in the decision-making process.

Figure 2: The performance of the Constituent CSR-HR-DAW Indices

Figure 2.1: The Broad Development CSR-HRDAW Index

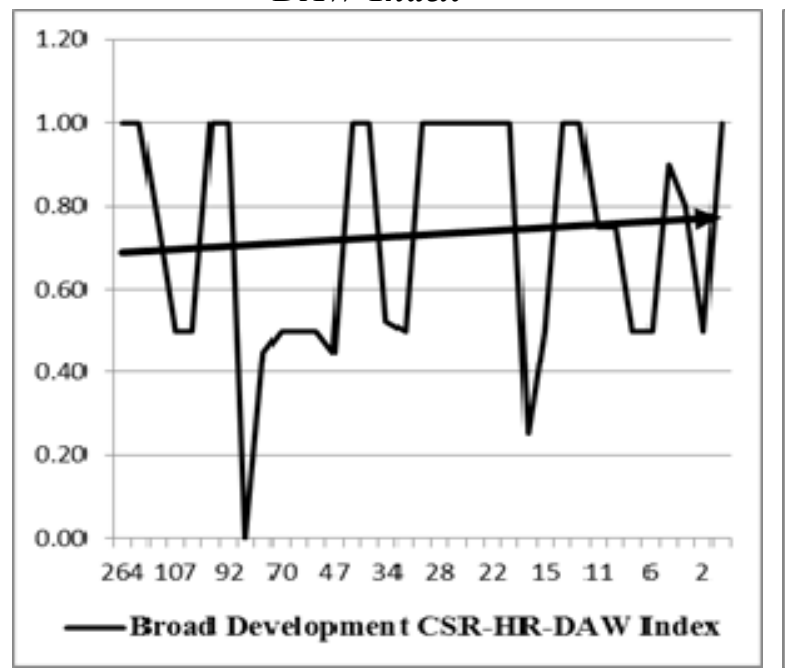

Figure 2.2: The Inclusive Concern CSR-HRDAW Index

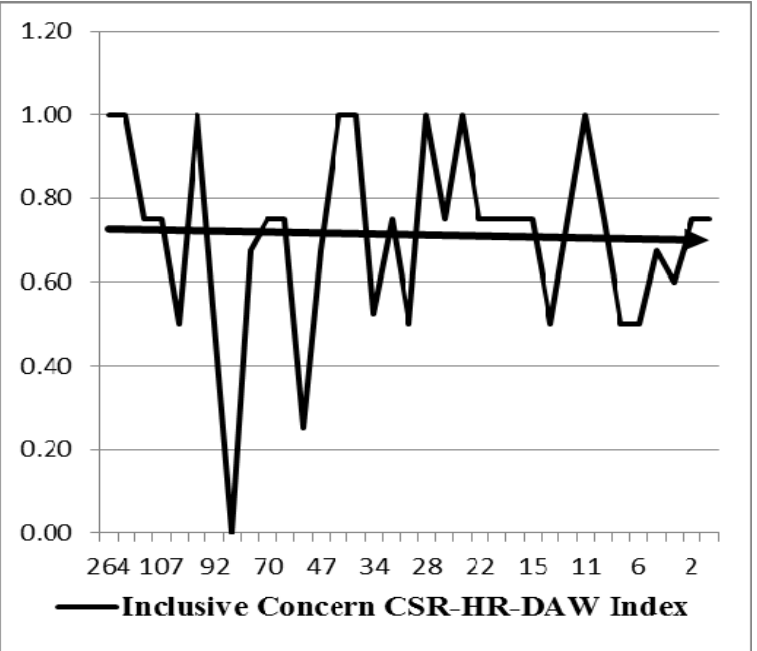


Figure 2.3: The Right Reward CSR-HR-DAW Index

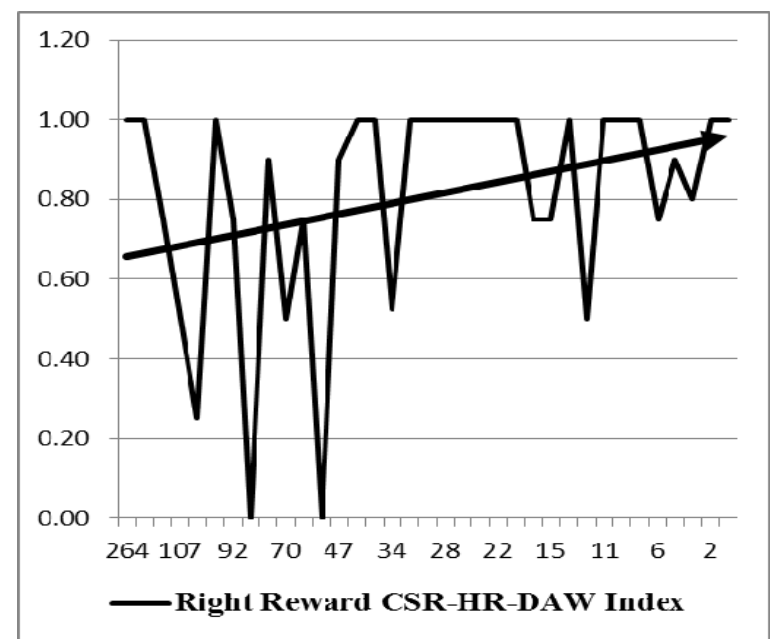

Source: Authors' representation using Deloitte 2010 report data and various CSR reporting sources.

When considering the average value of the global index at industrial level, as it could be noticed in Table 1, the analysis of the 35 selected companies revealed that the leading industry in terms of overall CSR-HR measures is the Technology, Media \& Telecommunications one. However, taking into account that within our sample this industry accounts only for two companies, the high score might be a consequence of this circumstance and, therefore, the score is likely to evidence signs of bias.

We consider more relevant the scores obtained for the other three industries (Energy \& Resources, Manufacturing and Consumer Business \& Transportation). Firstly, we notice that the three values are quite similar, fact that reflects that the considered top companies, on average, take into account the employee-oriented CSR measures regardless the industry. Secondly, the average scores are fairly high, suggesting again that, on average, the managers within these companies acknowledge their HR as a central stakeholder and asset and not only as merely as workforce.

Table 1: The CSR-HR-DAW Industry Average Indices

\begin{tabular}{|l|c|c|c|c|}
\hline Industry & $\begin{array}{c}\text { Energy \& } \\
\text { Resources }\end{array}$ & Manufacturing & $\begin{array}{c}\text { Consumer } \\
\text { Business \& } \\
\text { Transport }\end{array}$ & $\begin{array}{c}\text { Technology, } \\
\text { Media \& } \\
\text { Telecomm. }\end{array}$ \\
\hline \hline $\begin{array}{l}\text { Global CSR-HR-DAW } \\
\text { Industry Average Index }\end{array}$ & 0.72 & 0.78 & 0.74 & 0.92 \\
\hline $\begin{array}{l}\text { Broad Development CSR- } \\
\text { HR-DAW Industry Average } \\
\text { Index }\end{array}$ & 0.65 & 0.84 & 0.75 & 0.88 \\
\hline $\begin{array}{l}\text { Inclusive Concern CSR-HR- } \\
\text { DAW Industry Average Index }\end{array}$ & 0.69 & 0.69 & 0.75 & 0.88 \\
\hline $\begin{array}{l}\text { Right Reward CSR-HR- } \\
\text { DAW Industry Average Index }\end{array}$ & 0.82 & 0.82 & 0.71 & 1.00 \\
\hline Number of companies & 17 & 10 & 6 & 2 \\
\hline
\end{tabular}

Source: Authors' representation using Deloitte 2010 report data and various CSR reporting sources.

Moreover, if exploring the evolution of the three broad constituent indices, as previously shown, the Technology, Media \& Telecommunications industry seems to be the leading one, regardless the examined index. However, considering again the small sample criterion, the result could be considered as biased. Therefore, our attention is directed toward the remaining industries. However, we cannot determine a clear pattern: when implementing broad 
development measures for employees, the leading industries seem to be the Manufacturing one, when considering the right reward measures for employees, both the Energy \& Resources and the Manufacturing domains of activity lead, while when conducting inclusive concern measures for employees the Consumer Business \& Transportation sector dominates.

Table 2: The CSR-HR-DAW Country of Origin Average Indices

\begin{tabular}{|l|c|c|}
\hline Company & Foreign & National \\
\hline $\begin{array}{l}\text { Global CSR-HR-DAW Country of Origin } \\
\text { Average Index }\end{array}$ & 0.84 & 0.67 \\
\hline $\begin{array}{l}\text { Broad Development CSR-HR-DAW Country of } \\
\text { Origin Average Index }\end{array}$ & 0.85 & 0.63 \\
\hline $\begin{array}{l}\text { Inclusive Concern CSR-HR-DAW Country of } \\
\text { Origin Average Index }\end{array}$ & 0.76 & 0.67 \\
\hline $\begin{array}{l}\text { Right Reward CSR-HR-DAW Country of Origin } \\
\text { Average Index }\end{array}$ & 0.93 & 0.71 \\
\hline Number of companies & 16 & 19 \\
\hline
\end{tabular}

Source: Authors' representation using Deloitte 2010 report data and various CSR reporting sources.

When analysing the CSR-HR continuum from the perspective of the country of origin, both at general and constituents levels, the results, displayed in Table 2, indicate that the foreign companies within the analysed Central and Southeastern Europe countries show, indeed, more propensity towards employee-focused actions. Taking into account that, with few exceptions, the foreign studied companies are from highly developed countries, we consider that this result might be the consequence of the general guidelines reflected in the CSR group policy and corporate culture.

As far as the score of the average indices for the national companies are concerned, though sensitively lower than their counterparts, they reveal that these companies are focused on applying human resources CSR measures, while still being below the average value of the index, specifically 0.75. In addition, one can notice that the right reward measures for employees are the most important CSR-HR targets, regardless the country of origin, and this finding could be justified by adding that well-paid employees are usually more satisfied and more dedicated to the companies they are working for.

Table 3: The CSR-HR-DAW Operating Country Average Indices

\begin{tabular}{|l|c|c|c|c|}
\hline Country & $\begin{array}{c}\text { Global CSR- } \\
\text { HR-DAW } \\
\text { Country } \\
\text { Average } \\
\text { Index }\end{array}$ & $\begin{array}{c}\text { Broad } \\
\text { Development } \\
\text { CSR-HR- } \\
\text { DAW Country } \\
\text { Average } \\
\text { Index }\end{array}$ & $\begin{array}{c}\text { Inclusive } \\
\text { Concern } \\
\text { CSR-HR- } \\
\text { DAW Country } \\
\text { Average } \\
\text { Index }\end{array}$ & $\begin{array}{c}\text { Right } \\
\text { Reward CSR- } \\
\text { HR-DAW } \\
\text { Country } \\
\text { Average } \\
\text { Index }\end{array}$ \\
\hline \hline Bulgaria & 0.67 & 0.58 & 0.67 & 0.76 \\
\hline Romania & 0.72 & 0.80 & 0.70 & 0.65 \\
\hline Czech Republic & 0.75 & 0.69 & 0.71 & 0.84 \\
\hline Poland & 0.75 & 0.75 & 0.65 & 0.85 \\
\hline Slovenia & 0.75 & 0.75 & 0.80 & 0.70 \\
\hline Slovakia & 0.77 & 0.71 & 0.76 & 0.86 \\
\hline Hungary & 0.85 & 0.85 & 0.70 & 1.00 \\
\hline
\end{tabular}

Source: Authors' representation using Deloitte 2010 report data and various CSR reporting sources.

The analysis conducted from the overall perspective at the operating country level, displayed in Table 3, reflects that the companies applying more intensely CSR-HR measures 
are situated in Hungary. However, this could be explained by the fact that, apart from one company, all the other four are foreign global companies, conducting powerful CSR policies. Another country that has an above average score is Slovakia. Taking into account that within the analysed sample in Slovakia two companies are also well-known multinationals, with scores closed to unit, this highly compensates the lower scores of the local companies. As one can notice, three countries have the average score (Czech Republic, Poland and Slovenia). Like in the case of the Slovakian top companies, for the Czech and Polish top companies there are two foreign and three local ones. However, the foreign companies' scores are not that high to compensate the lower local scores, and, in some cases, are even lower.

An interesting example is Slovenia because all the analysed companies are local. Therefore, it could be deduced that the top companies within this country have quite strongly focused on employee-CSR policies. The last group of top companies is represented by the ones from Romania and Bulgaria, having below average scores. However, it could be noticed that the top Romanian companies' average score is close to the general average value, result reflecting the presence of two important foreign companies with high scores and a score equal to unity of a local company. When examining the case of Bulgaria, the result is not surprising considering that the only local company has a score equal to 0 .

When moving to the three constituent indices, Hungary seems to dominate the top when applying broad development and right reward measures for employees. Clustering the results, we formulate the following three general conclusions:

(1) Hungary and Romania have the highest score for the broad development measures for employees, Poland and Slovenia are in the middle of the top, while Bulgaria, the Czech Republic and Slovakia seem to have a score below average when discussing this class of measures for employees;

(2) For the inclusive concern measures for employees, the leading country is Slovenia, while Slovakia is the other country of the top with a score value over 0.75 for the same index. Consequently, the companies from all the other analysed countries seem to be, on average, less interested in adopting inclusive concern oriented measures for their employees;

(3) As far as the right reward measures for employees are concerned, 5 countries from our sample seem to be interested in thoroughly implementing these measures (Bulgaria, Czech Republic, Poland, Slovakia and Hungary).

\subsubsection{The performance of the CSR-HR-DAW Pillars}

The first results of the pillar-grounded analysis are displayed in Table 4 and reflect that four of the CSR-HR-DAW six pillars have an average value above the 0.75 score.

Table 4: The CSR-HR-DAW Pillars Average

\begin{tabular}{|l|c|}
\hline Pillar & $\begin{array}{c}\text { CSR-HR-DAW } \\
\text { Pillars Average }\end{array}$ \\
\hline \hline Participation of employees in the decision-making process - DAW & 0.53 \\
\hline Work-private life balance - DAW & 0.56 \\
\hline Equal opportunities \& promotion of diversity - DAW & 0.81 \\
\hline Fair payment \& financial support for employees - DAW & 0.84 \\
\hline Improvement of labour conditions \& job satisfaction - DAW & 0.93 \\
\hline Personnel training \& development - DAW & 0.94 \\
\hline
\end{tabular}

Source: Authors' representation using Deloitte 2010 report data and various CSR reporting sources.

The results are encouraging, reflecting that the overall index is not merely a consequence of some high scored components, but a reflection of a tendency towards a consolidated strategy of employee-oriented CSR measures within the Central and Southeastern Europe top 
analysed companies. The results are not surprising in terms of preferred pillars within the analysed countries as, being companies from emerging and frontier countries, one can expect that these ones apply mostly the basic and strongly company-related measures. Therefore, one could expect that the pillars regarding the work-private life balance and those reflecting the involvement in the decision-making process to receive, on average, less attention, for the time being.

Regarding the analysis performed at the level of each of the six pillars, considering the rank of the companies within the Deloitte CE 2010 Top 500 Companies in terms of revenues from sales, the results are displayed in Figure 3 (Figures 3.1 up to Figures 3.6). Source: Authors' representation using Deloitte 2010 report data and various CSR reporting sources

Figure 3: The performance of the CSR-HR-DAW Pillars

Figure 3.1: Personnel training \& development - DAW

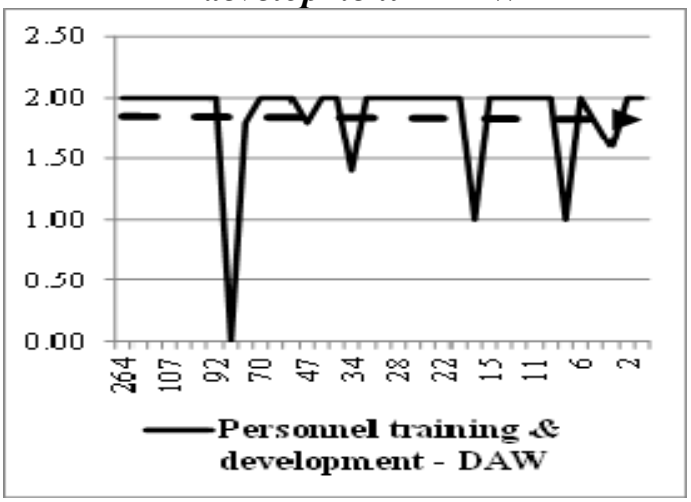

Figure 3.2: Improvement of labour conditions \& job satisfaction $-D A W$

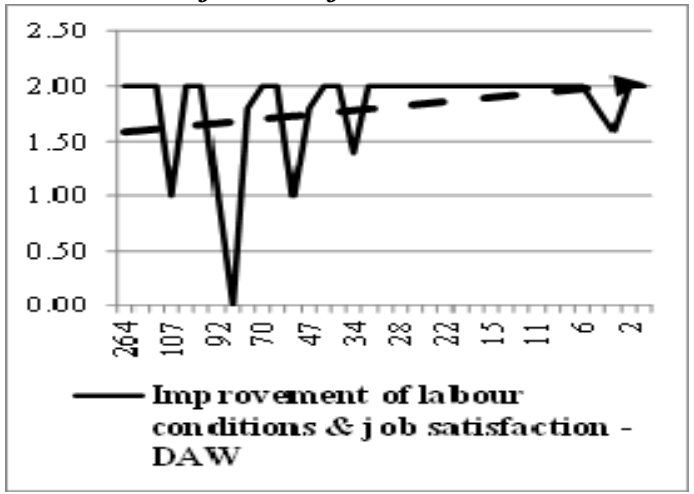

Figure 3.3: Fair payment \& financial support for employees - DAW

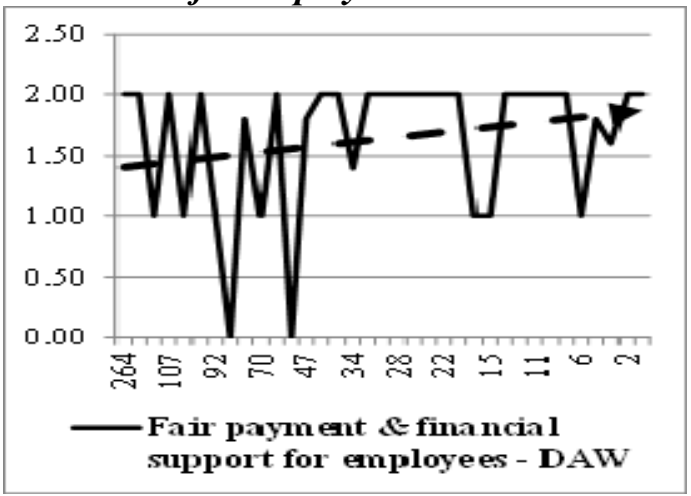

Figure 3.4: Equal opportunities \& promotion of diversity - DAW

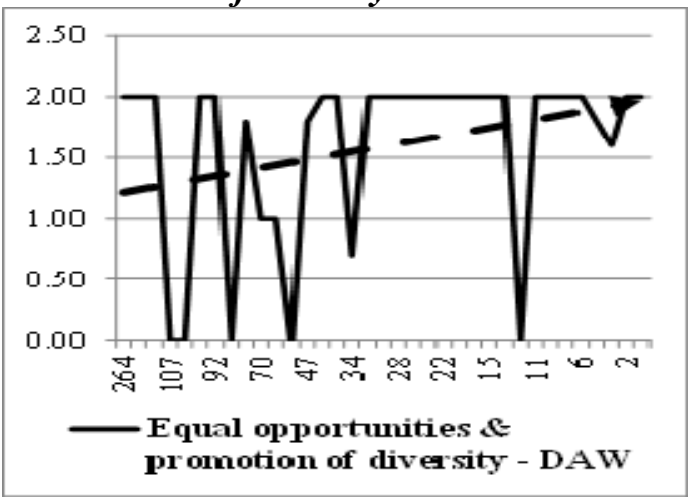

Figure 3.5: Work-private life balance for employees-DAW

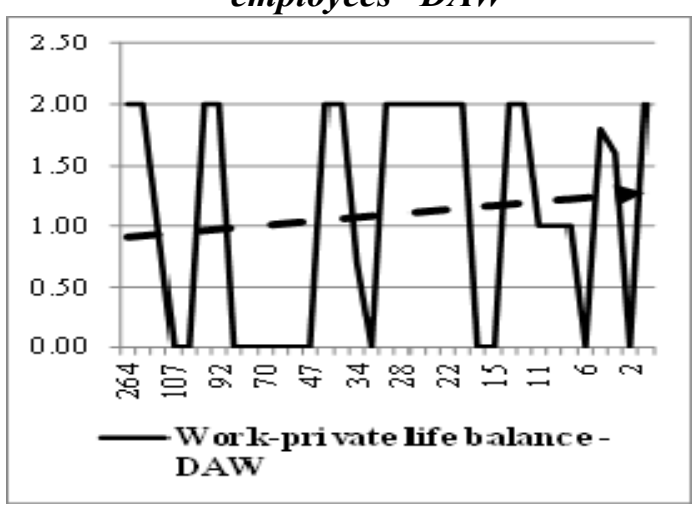

Figure 3.6: Participation of employees in the decision-making process - DAW

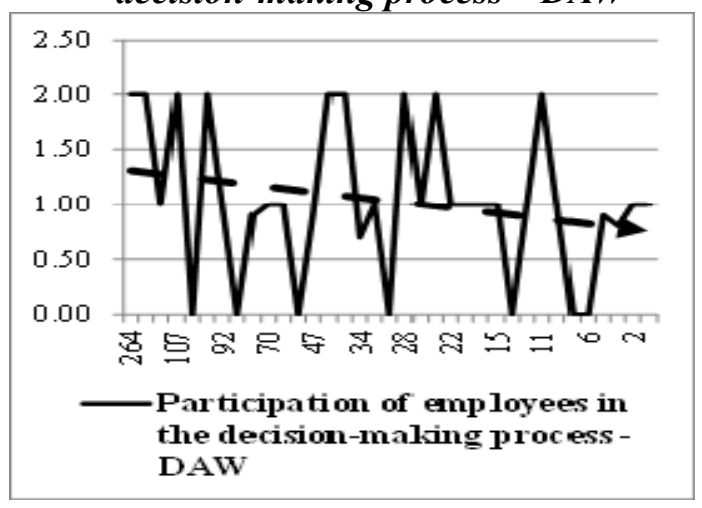


As it could be noticed in Figures 3.2, 3.3, 3.4 and 3.5, the pillars regarding Improvement of labour conditions \& job satisfaction, Fair payment \& financial support for employees, Equal opportunities \& promotion of diversity and Work-private life balance seem to unveil a slight positive trend with respect to the rank of the company within the Deloitte CE Top 500 Companies in terms of revenues from sales. These results reveal that the economic performance of the companies, reflected by the revenues from sales, boosts the before mentioned actions targeting the employees of the companies from the Central and Southeastern Europe countries. The other two pillars, Personnel training \& development and Participation of employees in the decision-making process, as can be noticed in Figure 3.1 and 3.6, seem to have a negative trend with respect to the company's rank, which could be a result of the fact that the higher the economic performance, the more company will invest in some or all of the other four pillars. Another possible interpretation of this result could be the high degree of centralization of the decision-making in case of very large companies, that do not afford to share the strategic decisions with their employees, but prefer to keep them at the top management level. In the end, it could be concluded that leading companies in Central and Southeastern Europe countries, considered according to their increasing rank in the Deloitte CE Top 500 Companies, tend to allocate a higher importance to equal opportunities and promotion of diversity measures, to decrease the implication of their employees in the decision-making process and to equally consider personnel training and development measures no matter their position in the top, this last type of measures being considered an essential one for their business activities (this conclusion is also supported by the figures presented in Table 4).

\section{RECOMMENDATIONS AND CONCLUSIONS}

With reference to the relationship between CSR and HR, two main trends could be identified at global level: the first one, considered as elementary, refers to the CSR measures that the companies may apply for their employees in order to increase their retention and satisfaction degree, recognizing the importance of the personnel in assuring the corporate competitiveness (our empirical analysis is included in this first category); the second one, regarded as more complex than the former one, refers to the promotion of corporate values and CSR policies through the employees that are already well-motivated in the companies and are now communicating further on the model of corporate involvement in ecological, social and ethical issues (this approach comes across rather in the most developed countries of the world, that have already achieved a specific level of economic performance at corporate and national level and are strongly motivating their employees through all six types of measures presented in this research).

The empirical analysis conducted for the 35 companies pertaining to Central and Southeastern Europe countries emphasized that, in the last years, major corporate advancements took place in terms of including and thoroughly applying employee-related CSR measures in the business strategies of the companies. The economic and financial performance of the analysed companies in Central and Southeastern Europe countries encourages the overall employee-related CSR measures. At this point, although the need for more sophisticated employee-dedicated measures is strongly affirmed at corporate and national level, fair payment and financial support for employees, as well as equal opportunities and promotion of diversity seem to be the top issues of corporate agendas in the field, especially in the analysed countries. In the coming years, more focus is needed on those specific measures targeting the involvement of the employees in the decision-making process and a better work-life balance, considered to be more sensitive areas. Both the analyses of the 
performance of the CSR-HR-DAW Indices and the CSR-HR-DAW Pillars confirmed these results.

The general conclusion of the present research is aimed at reaffirming the strong engagement of the analysed companies in Central and Southeastern Europe countries in the employee-related CSR measures in the last years, as a solid recognition of the role played by employees in strengthening corporate competitiveness. Along these lines, companies are equally interested in promoting the interests of their employees and are becoming closer to the strategic objective of the European Commission of a "highly competitive social market economy".

\section{NOTE}

The two authors contributed equally to this work. The present paper represents an improved and updated version of Iamandi, IE \& Constantin, LG 2012: 'Consolidating Human Resource Management through Corporate Social Responsibility Practices in Central and Southeastern Europe', paper presented in the International Conference on Management of Human Resources 2012: Management - Leadership - Strategy - Competitiveness, Gödöllö, Hungary, 14-15 ${ }^{\text {th }}$ June 2012, and published in the Proceedings of the International Conference on Management of Human Resources 2012: Management - Leadership - Strategy Competitiveness (Editor: Illés B. Cs.), Volume I, Rosental Kft. Publishing House, Gödöllö, Hungary, 14-15th June 2012, pp. 241-248.

\section{ACKNOWLEDGEMENTS}

This work was co-financed from the European Social Fund through Sectoral Operational Programme Human Resources Development 2007-2013, project number POSDRU/89/1.5/S/59184 "Performance and Excellence in Postdoctoral Research in Romanian Economics Science Domain".

\section{REFERENCES}

1. Austrian Institute for SME Research 2007: The Importance of Corporate Social Responsibility-CSR for SMEs [Importanţa Responsabilităţii Sociale Corporative - CSR pentru IMM-uri - in Romanian], European Commission, www.csr-insmes.eu/downloads/brochure_romanian.pdf, accessed on March 30, 2012, downloaded on April 4, 2012

2. Deloitte 2010: Central Europe Top 500 Companies, Deloitte, http://www.deloitte.com/assets/DcomGlobal/Local\%20Assets/Documents/Deloitte\%20Research/CETOP500/2010/CETOP50 0_Ranking_2010.pdf, accessed on February 20, 2012, downloaded on April 4, 2012

3. European Commission 2011: A Renewed EU Strategy 2011-2014 for Corporate Social Responsibility, $\operatorname{COM(2011)~} 681$ final, Brussels, $\mathrm{http}$ ://ec.europa.eu/enterprise/newsroom/cf/_getdocument.cfm?doc_id=7010, accessed on October 26, 2011, downloaded on April 4, 2012

4. Global Reporting Initiative (GRI) 2011: G3.1 Sustainability Reporting Guidelines, https://www.globalreporting.org/reporting/latest-guidelines/Pages/default.aspx, accessed on February 23, 2012, downloaded on April 4, 2012 
5. Iamandi, IE 2011: 'Strategic Approach of Corporate Social Responsibility Key-Drivers for Increasing Competitiveness at the European Level', Economic Review, No. 3 (56) / 2011, pp. 180-187, http://economice.ulbsibiu.ro/revista.economica/archive/RE\%203-562011.pdf, accessed on February 23, 2012, downloaded on April 1, 2012

6. Iamandi, IE 2010: Corporate Social Responsibility in Multinational Companies [Responsabilitatea socială corporativă în companiile multinaţionale - in Romanian], Economic Publishing House, Bucharest

7. Iamandi, IE \& Constantin, LG 2012: 'Consolidating Human Resource Management through Corporate Social Responsibility Practices in Central and Southeastern Europe', paper presented in the International Conference on Management of Human Resources 2012: Management - Leadership - Strategy - Competitiveness, Gödöllő, Hungary, 14$15^{\text {th }}$ June 2012, and published in the Proceedings of the International Conference on Management of Human Resources 2012: Management - Leadership - Strategy Competitiveness (Editor: I. B. Csaba), Volume I, Rosental Kft. Publishing House, Gödöllö, Hungary, 14-15th June 2012, pp. 241-248

8. Nicolescu, O 2001: Comparative Management: EU, USA and Japan [Management comparat: Uniunea Europeană, Statele Unite ale Americii şi Japonia - in Romanian], $2^{\text {nd }}$ Edition, Economic Publishing House, Bucharest

9. Popa, I \& Filip, R 1999: International Management [Management internaţional - in Romanian], Economic Publishing House, Bucharest

10. Strandberg, C 2009: The Role of Human Resource Management in Corporate Social Responsibility: Issue Brief and Roadmap, Strandberg Consulting, Burnaby $\mathrm{BC}$, http://corostrandberg.com/, accessed on February 25, 2012, downloaded on March 4, 2012

11. ***, Inno Train CSR project, funded by the Leonardo da Vinci Programme of the EU, http://www.csr-training.eu/en/csr-training/fields-of-action-of-csr/, accessed on April 20, 2012

12. http://www.agrofert.cz/, accessed on April 28, 2012

13. http://www.arcelormittal.com/, accessed on April 28, 2012

14. http://www.audi.hu/, accessed on April 28, 2012

15. http://www.aurubis.com/en/, accessed on April 28, 2012

16. http://www.cez.cz/en/home.html, accessed on April 28, 2012

17. http://www.dacia.ro/, accessed on April 28, 2012

18. http://www.eon-foldgaz-trade.com/, accessed on April 28, 2012

19. http://www.fiat.pl/, accessed on April 28, 2012

20. http://www.foxconn.cz/, accessed on April 28, 2012

21. http://www.ge.com/hu/en/, accessed on April 28, 2012

22. http://www.gorenjegroup.com/en/, accessed on April 28, 2012

23. http://www.jeronimomartins.pt/o-grupo/onde-estamos/polonia.aspx?lang=en, accessed on April 28, 2012

24. http://www.lukoil.bg/, accessed on April 28, 2012

25. http://www-en.mercator.si/mercator_group, accessed on April 28, 2012

26. http://www.merkurgroup.eu/, accessed on April 28, 2012

27. http://www.metro.ro/public/Home, accessed on April 28, 2012

28. http://www.mol.hu/en/, accessed on April 28, 2012

29. http://www.nek.bg/cgi, accessed on April 29, 2012

30. http://www.nokia.com/hu-hu/, accessed on April 29, 2012

31. http://www.omv.bg/, accessed on April 29, 2012

32. http://www.orlen.pl/en/Pages/default.aspx, accessed on April 29, 2012

33. http://www.petrol.eu/, accessed on April 29, 2012 
34. http://www.petrom.com/, accessed on April 29, 2012

35. http://www.pgesa.pl/en/Pages/default.aspx, accessed on April 29, 2012

36. http://www.pgnig.pl/, accessed on April 29, 2012

37. http://www.revoz.si/en/index.cp2, accessed on April 29, 2012

38. http://www.rompetrol.com/, accessed on April 29, 2012

39. http://www.rwe.cz/en/39/, accessed on April 29, 2012

40. http://www.samsung.com/sk/, accessed on April 29, 2012

41. http://www.seas.sk/sk/uvodna-stranka, accessed on April 29, 2012

42. http://new.skoda-auto.com/en/Pages/homepage.aspx, accessed on April 29, 2012

43. http://www.slovnaft.sk/sk/, accessed on April 29, 2012

44. http://www.spp.sk/, accessed on April 29, 2012

45. http://www.Vw.sk/, accessed on April 29, 2012 